\title{
Sistem Informasi Penjualan Elektronik pada Ud.Karya Elektrik Jakarta
}

\author{
${ }^{1}$ Mohamad Syaiful Amri, ${ }^{2}$ Agus Junaidi \\ ${ }^{1,2}$ Sistem Informasi, STMIK Nusa Mandiri \\ 1.

\begin{tabular}{ccc}
\hline Diterima & Direvisi & Disetujui \\
$04-11-2020$ & $09-11-2020$ & $15-12-2020$ \\
\hline
\end{tabular}

\begin{abstract}
Abstrak - Penjualan merupakan suatu kegiatan proses jual beli yang dilakukan oleh dua orang atau lebih yang memberikan keuntungan bagi suatu perusahaan atau perorangan. Adapun beberapa masalah yang di hadapi pada Toko UD. Karya Elektrik Jakarta ini yaitu proses transaksi yang masih dilakukan secara manual dan data penjualan dilakukan dengan menggunakan buku pencatatan, sehingga sering sekali terjadi kerangkapan data ataupun tidak tercatatnya data oleh operator. Oleh karena itu untuk membantu memajukan toko UD.Karya Elektrik dalam melakukan transaksi penjualan maka dibuat sistem penjualan dari yang manual menjadi aplikasi dan juga laporan dari manual menjadi bentuk print out atau soft copy. Adapun metode yang digunakan yaitu metode waterfall, metode waterfall ini dipilih karena proses transaksi harus dilakukan secara bertahap mulai dari konsumen memilih barang hingga melakukan proses pembayaran. Dengan dibuatnya sistem penjualan pada toko UD. Kriya Elektrik membuat proses transaksi lebih cepat dan juga mendapatkan hasil yang akurat dan juga data penjualan tidak akan terjadi kerangkapan data karena data sudah terkomputerisasi dan juga data penjualan sudah disimpan pada satu database yang aman.
\end{abstract}

Kata Kunci : Database, Jual beli, Penjualan, Transaksi, Waterfall.

\begin{abstract}
Sales is an activity of buying and selling process carried out by two or more people who provide benefits for a company or individual. As for some of the problems faced at the UD store. This Electrical Work is a transaction process that is still done manually and sales data are carried out using a recording book, so that there are often duplicate data or data not recorded by the operator. Therefore, to help advance the UD.Karya Elektrik store in conducting sales transactions, a sales system is made from the manual into an application and also reports from the manual into a printout atau soft copy. The method used is the waterfall method, the waterfall method was chosen because the transaction process must be carried out in stages starting from the consumer choosing goods to making the payment process. With the creation of a sales system at the UD store. Kriya Elektrik makes the transaction process faster and also gets accurate results and also sales data will not occur duplicate data because the data is computerized and also the sales data has been stored in a secure database
\end{abstract}

Keywords: Database, Buying and selling, Sales, Transaction, Waterfall

\section{Pendahuluan}

Seiring dengan berjalannya teknologi informasi, muncul berbagai macam layanan yang dapat memenuhi kebutuhan informasi. Peran teknologi informasi menjadikan pengolahan informasi menjadi sangat mudah. Tidak dapat dipungkiri, pengolahan data menjadi suatu informasi pada sebuah perusahaan yang dikelola sangat baik dan juga bisa membantu serta menunjang kegiatan manajemen dan operasional dengan menerapkan sistem informasi [1].
Demi meningkatkan kualitas pelayanan informasi dan mempercepat proses penjualan toko UD. Karya Elektrik harus menggunakan sistem komputerisasi dalam melakukan proses penjualan sehingga proses pekerjaan akan menjadi lebih tertib, dan juga dapat

memberikan informasi yang akurat dan cepat. Setelah melihat dan menganalisis prosedur penelitian, peneliti menemukan kendala transaksi yang dapat mempengaruhi kinerja terhadap sistem yang telah ada.Adapun judul yang dikemukakan dalam penelitian. 
pengembangan ini, penulis menggunakan metode waterfall. Adapun tahapan dalam metode ini adalah :

1. Penentuan dan analisis spesifikasi Jasa, kendala dan tujuan dihasilkan dari konsultasi dengan pengguna sistem kemudian dibuat dalam bentuk yang dapat dimengerti oleh pemakai.

2. Desain sistem, proses desain sistem membagi kebutuhan-kebutuhan menjadi sistem informasi atau perangkat keras, dari hasil tersebut menghasilkan sebuah arsitektur sistem keseluruhan.

3. Implementasi dan uji coba unit, selama ditahap ini desain sistem informasi sebagai sebuah program lengkap atau sebuah unit diuji.

4. Uji coba sistem, program di uji menjadi sistem yang lengkap untuk meyakinkan bahwa sesuai dengan persyaratan sistem informasi yang telah dipenuhi.

5. Pemeliharaan sistem, sistem dipasang lalu digunakan dan dilakukan pemeliharaan sistem secara berkala.[9]

\section{Rancangan Sistem dan Program Usulan}

3.0 Proses bisnis

Konsumen memilih barang di Toko UD.Elektrik, kemudian pramuniaga menerima barang yang konsumen pilih, lalu pramuniaga menghitung harga barang yang dipilih oleh konsumen, setelah dihitung pramuniaga memberikan nota pembelian kepada konsumen, setelah itu konsumen membayarkan sesuai harga yang ada di nota pembelian.

3.1 Analisa Kebutuhan Software

A. Tahapan Analisis

Sistem informasi penjualan toko berbasis desktop dimana pramuniaga dapat dengan mudah melakukan transaksi, juga membantu dalam membuat laporan penjualan toko dan membatu menyimpan dan pencarian data kembali sehingga lebih akurat,efektif dan efesien dalam penggunaan waktu dan biaya. Berikut ini spesifikasi kebutuhan (System requirement) dari sistem informasi desktop ini:

\section{Halaman Admin:}

1. Data Barang

A1. Admin dapat menambahkan barang baru.

A2. Admin dapat mengapus barang.

A3. Admin dapat mengedit barang.

A4. Admin dapat mencari barang.

A5. Admin dapat print data barang masuk.

A6. Admin dapat menghapus barang yang salah masuk.

\section{Data Petugas}

A7. Admin dapat menambah petugas

A8. Admin dapat menghapus nama petugas

A9. Admin dapat mengedit nama petugas.
A10.Admin dapat print nama petugas.

A11.Admin dapat menghapus petugas yang salah masuk.

3. Riwayat

A.12. Admin dapat melihat riwayat penjualan.

A13. Admin dapat reset riwayat penjualan.

A14. Admin dapat mencari riwayat penjualan

\section{Halaman Petugas:}

1. Halaman transaksi :

B1. Petugas bisa mencari barang.

B2.. Petugas bisa menambah pembelian barang.

B3. Petugas bisa melakukan reset penjualan.

B4. Petugas bisa print hasil penjualan.

B5. Petugas bisa melakukan transaksi penjualan

\section{Halaman daftar menu :}

B6. Petugas bisa melihat stock barang yang keluar.

\section{Halaman riwayat :}

B7. Petugas bisa melihat riwayat transaksi

\section{B. Use case Diagram}

Use case diagram adalah suatu diagramyang menggambarkan hubungan actor terhadap sistem diagram use case digunakan mendeskripsikan apa yang dilakukan oleh sistem.

\section{Use Case diagram Halaman Admin}

Berikut use case diagram dimana merupakan usulan sistem berjalan dari penulis, secara umum ini

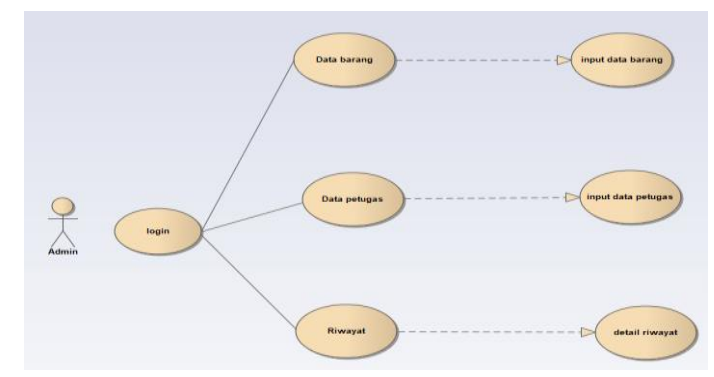

yang dapat dilakukan oleh admin di halaman admin

Sumber : hasil Penelitian (2020)

\section{Gambar 1. Use case halaman Admin}


2. Use case Halaman Petugas

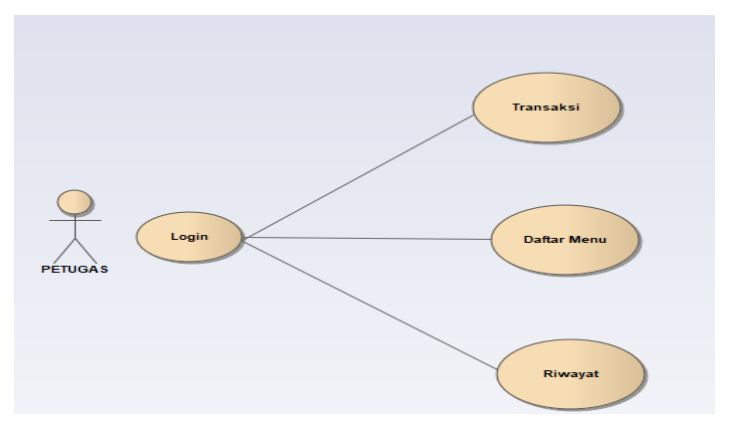

Gambar 2. Use case halaman petugas

Berikut use case diagram dimana merupakan usulan system berjalan dari penulis, secara umum ini gambara yang dapat dilakukan oleh petugas di halaman petugas

\section{Activity Diagram}

Activity Diagram adalah teknik menggambarkan suatu alur kerja program yang berisi pilihan, pengulangan dalam suatu program.

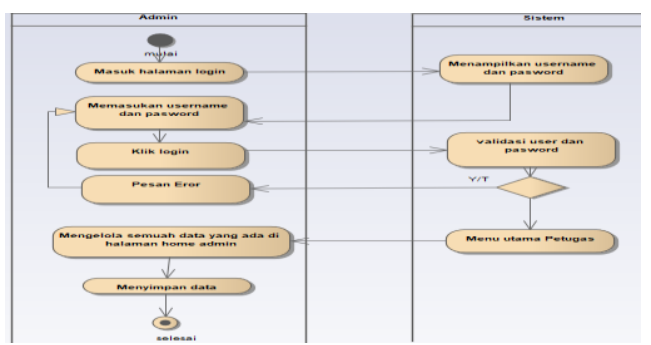

Gambar 3. Activity Diagram Admin

3.2 Desain

1. Entity relationship Diagram (ERD)

Entity Relationship Diagram (ERD) adalah suatu bentuk diagram yang menjelaskan hubungan antar objek-objek data yang mempunyai hubungan antar relasi. ERD digunakan untuk menyusun struktur data dan hubungan antar data, berikut spesifikasi database pada sistem ini sebagai berikut:

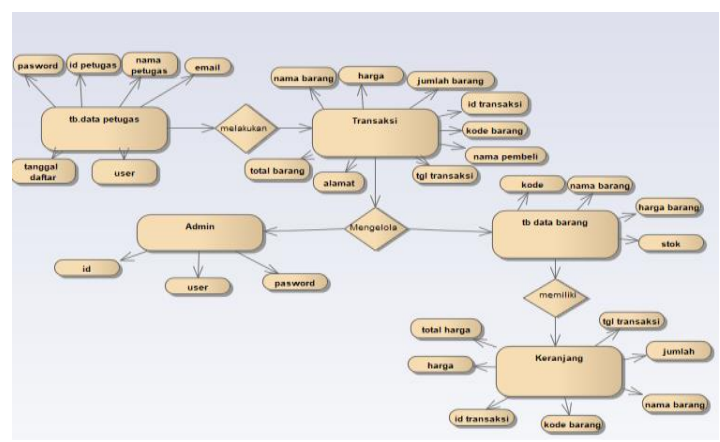

Gambar 4. Entity Relationship Diagram
2. Logical Record Strukture (LRS)

Berikut gambaran Lrs pada aplikasi ini terdapat admin, petugas, barang, keranjang, transaksi sebagai fieldnya.

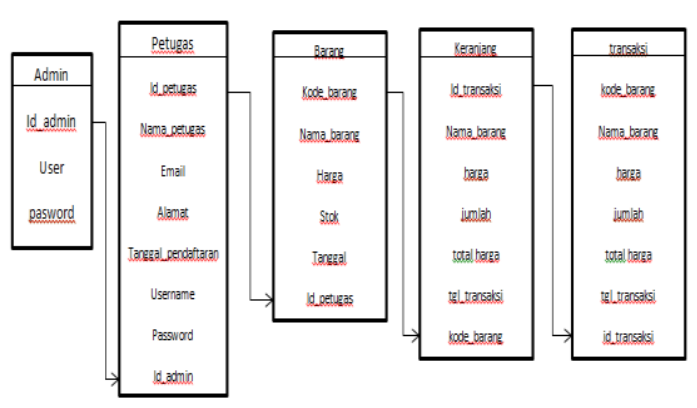

Gambar 5. Logical Record Struktur Penjualan

\subsection{User Interface}

Menggambarkan suatu tampilan program dari sistem yang diusulkan.

a. Halaman Utama Aplikasi

Dibawah ini merupakan tampilan awal program sebelum masuk kedalam sistem.

SELAMAT DATANG DI TOKO UD.KARYA ELEKTRIK

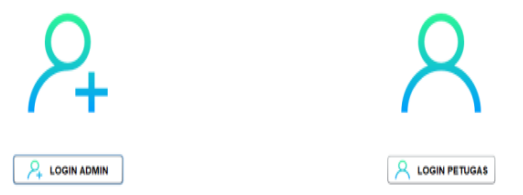

Terdapat dua pilihan ada sebagai admin dan juga ada sebagai petugas.

\section{Gambar 6. Halaman Utama Aplikasi}

b. Halaman Login Admin

Dibawah ini merupakan tampilan awal program untuk melakukan $\log$ in kedalam sistem. Terdapat kolom user dan password serta tombol log in

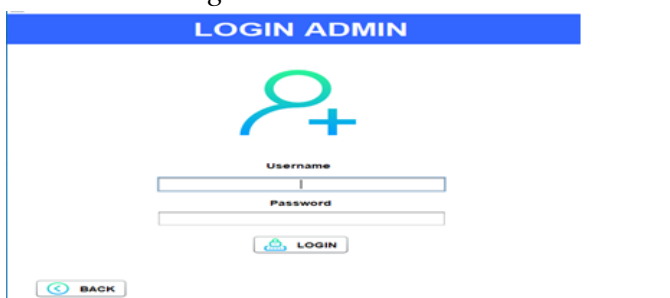

Gambar 7. Halaman Login Admin 
c. Halaman Menu Utama Admin

Dibawah ini merupakan tampilan isi program yang mana terdapat tombol data barang, data petugas, riwayat, dan logout.

\section{MENU ADMIN}
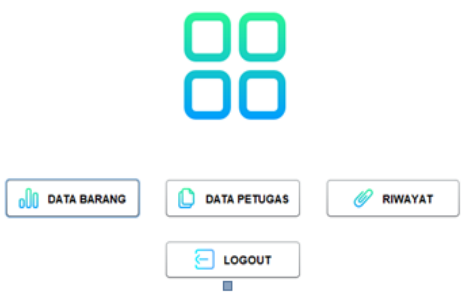

\section{Gambar 8. Halaman Menu Utama Admin}

d. Halaman Data Barang

Dibawah ini merupakan tampilan isi dari form data barang, disini bisa melakukan penambahan barang baru, menghapus barang, edit barang, dan print data barang.

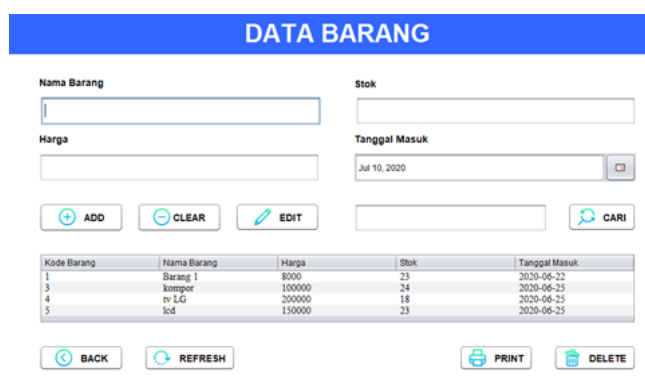

Gambar 9. Halaman Data Barang Admin

e. Halaman Petugas

Dibawah ini merupakan tampilan isi dari form data petugas, disini bisa menambahkan petugas baru, edit petugas,menghapus, dan print.

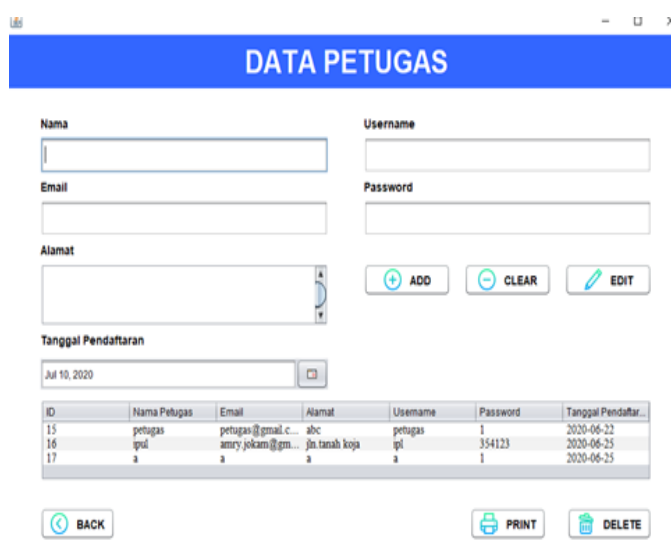

Gambar 10. Halaman Petugas f. Riwayat

Dibawah ini merupakan tampilan isi dari form riwayat, disini kegiatan transaksi akan masuk kedalam riwayat.

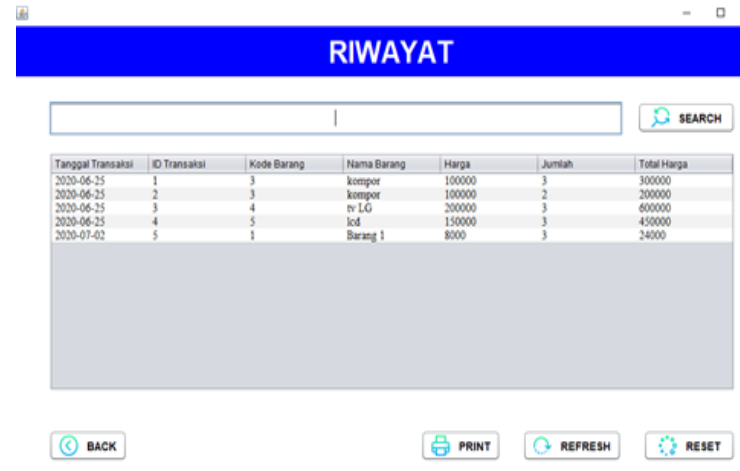

Gambar 11. Halaman Riwayat

\section{Kesimpulan}

Berdasarkan hasil dari riset lapangan serta proses pembuatan aplikasi ini, maka penulis mengambil kesimpulan sebagai berikut:

1. Sistem aplikasi penjualan pada Toko.UD.Karya Elektrik Jakarta sudah dapat digunakan secara offline. Aplikasi ini dapat membantu dan memudahkan para pramuniaga toko dalam hal melakukan transaksi dari yang manual menjadi terkomputerisasi.

2. Dapat memantau keseluruhan kegiatan transaksi

3. Aplikasi ini dapat mencetak laporan barang, laporan pegawai \& cetak struk transaksi penjualan.

4. Dalam aplikasi ini dapat meminimalisir kecurangan pramuniaga dalam transaksi.

Daftar Pustaka

[1] P. Aren and N. E. T. di, "perancangan sistem informasi penjualan voucher game online berbasis desktop," vol. 01, no. 01, pp. 8794, 2020.

[2] B. [1] B. Dekstop, P. Cv, and H. Koperpu, "Perancangan aplikasi penjualan retail," vol. 1, no. 2, pp. 20-27, 2018.Dekstop, P. $\mathrm{Cv}$, and H. Koperpu, "perancangan aplikasi penjualan retail," vol. 1 , no. 2 , pp. 20-27, 2018.

[3] J. Hutahean, konsep sistem informasi. yogyakarta: deepublish, 2014.

[4] Elisabet yunaeti angraeni dan rita irviani, pengantar sistem informasi. yogyakarta: Andi, 2017.

[5] I. Y. Supardi, semua bisa menjadi programmer java basic programming. Jakarta: pt.elex media komputindo, 2010. 
[6] Fatkhudin, "toko elektronik lubada jaya kajen dengan," vol. 6, no. 1, pp. 23-36, 2016.

[7] Destiana \& Fajrin, "Sistem informasi penjualan barang berbasis web pada pt. catur daya persada jakarta," paradig. - J. Komput. dani inform., vol. 16, no. 2, pp. 32-43, 2014, [Online].

Available: http://ejournal.bsi.ac.id/ejurnal/index.php/pa radigma/article/view/775/634.

[8] Nugraha and Octasia, "sistem informasi penjualan kaos berbasis web pada distro sickness berbasis e-commerce," sniptek, pp. 294-297, 2016, doi: 10.1016/j.carbon.2006.06.004.

[9] P. huruf, A. dan, W. pada, a. usia, m. pembelajaran, and B. Multi, "paradigma vol. xvii no. 1 maret 2015 pengenalan huruf, angka dan warna pada anak usia dini melalui pembelajaran berbasis multi media," vol. XVII, no. 1, pp. 28-35, 2015.

[10] R. Hidayat, S. Marlina, and L. D. Utami, "Perancangan sistem informasi penjualan barang handmade berbasis website dengan metode waterfall," simnasiptek 2017, p. A$178,2017$.
[11] V. Sofica, A. Widiatmoko, and k. novel, "bianglala informatika program complaint online untuk departemen edp pada pt indomarco prismatama cabang bekasi menggunakan framework codeIgniter ISSN : 2338-9761 ( Online ), 2338-8145 ( Print ) bianglala informatika," vol. 7, no. 2, pp. 8289, 2019.

[12] A. P. Andita and P. Astuti, "Penerapan metode waterfall dalam pembuatan sistem informasi dana kas kecil pada pt . natur pesona indonesia," vol. 8 , no. 1 , pp. $36-45$, 2020.

[13] J. K. informatika et al., "sistem informasi penjualan," vol. 3, no. 2, pp. 143-151, 2015.

[14] N. Muthia, H. Amalia, A. Puspita, A. F. Lestari, and S. I. Akuntansi, "rancang bangun sistem informasi akuntansi penjualan dengan model waterfall berbasis java desktop," vol. 5, no. 1, pp. 15-22, 2019.

[15] B. Sudarsono and A. bsi karawang, "perancangan program sistem informasi persediaan dan penjualan barang pada toko sparepart motor," Simnasiptek 2017, vol. 1, no. 1, p. 2017, 2017. 